\author{
Journal of The Japan Institute of Light Metals, Vol. 66, No. 6 (2016), 324-328 \\ (C) 2016 The Japan Institute of Light Metals
}

\title{
Basics of refractories for aluminum melting furnaces
}

Kazuya NODA*

Keywords: refractory, monolithic refractory, castable, low cement castable, energy saving

\section{1. まえがき}

耐火物とは，「 $\left\lceil 500^{\circ} \mathrm{C}\right.$ 以上の定形耐火物及び最高使用温度 が $800^{\circ} \mathrm{C}$ 以上の不定形耐火物，耐火モル夕ル並びに耐火断熱 れんが」とJIS R2001で定義されているとおり，「高い温度に 耐えるもの」である。このためアルミニウム産業のほかにも， 鉄鋼, 非鉄金属, ガラス, セメント, 石油化学の製造プロセ スや，ごみ焼却炉，ボイラー，煙突など，高温となる設備の 多くに使用されている。しかし，その重要性のわりに，社会 における認知度は低いようである。

耐火物は，炉内の高温雲囲気，侵食雲囲気から，設備本体 を保護するために建築される消耗品であり，その消耗具合に 応じて交換される。製鉄プロセスにおける耐火物の使用環境 は極めて過酷であり，その消耗は早い。さまざまな高温設備 で使用されている耐火物であるが，その消費量は製鉄プロセ スが最も多く，耐火物消費量全体の約 70\%を占める。

今回, 耐火物の基礎的な知識, アルミニウム産業で使用さ れる主な耐火物の特徵とこれを使用するうえでの留意点, そ して最近の取り組みを紹介する。

\section{2. 耐火物の基礎的な知識}

\section{1 製造方法による分類}

耐火物は，製造方法によって「電鋳耐火物」「結合耐火物」 「不定形耐火物」の大きく3つに分類される。製造方法によっ て各耐火物の微細組織は異なり，表１のような特徵を示す。 電鋳耐火物は，耐火物原料を高温で溶融し，鋳造することに

表 1 耐火物の製造方法による分類

\begin{tabular}{|c|c|c|c|}
\hline & 製品製法 & 組織 & 特徴 \\
\hline 電鋳耐火物 & 溶融 - 凝固 & $\begin{array}{l}\text { 極めて } \\
\text { 緻密 }\end{array}$ & \begin{tabular}{|l|} 
高耐食 \\
低耐熱スポーリング
\end{tabular} \\
\hline 結合耐火物 & 成形·焼結 & \multirow[b]{2}{*}{ 緻密 } & \multirow{2}{*}{$\begin{array}{l}\text { 耐食性と } \\
\text { 耐熱スポーリング性の } \\
\text { バランス良好 }\end{array}$} \\
\hline 不定形耐火物 & 混合 & & \\
\hline
\end{tabular}

よって得られる形状をもった耐火物製品である。結合耐火物 は, 耐火物原料を加圧成型し, 高温で焼成することによって 得られる形状をもった耐火物製品である。一方, 不定形耐火 物は，耐火物原料を混合しただけの形状をもたない耐火物製 品である。電鋳耐火物や結合耐火物は，プラントに合わせて 設計された形状で製品が出荷され, 現地にて製品が積み上げ られることにより炬壁となる。不定形耐火物は, プラントに 合わせて現地で形つくられて炉壁となる。このため不定形耐 火物炉壁の微細組織は, 現地で形つくる際の条件（施工条 件)の影響を受けることになる。不定形耐火物炉壁の性能を， 設計どおりに発揮させるためには, 現地施工作業の管理が重 要となる。電鋳耐火物や結合耐火物の炉壁を建築するときに は，製品を積み上げたときにできる製品間の隙間（目地）を 埋めるために目地モルタルを使用する。製品部分に比べて目 地部分の性能が低くなることが避けられないため, 目地部分 の損耗が早くなるケースや高温処理物が目地に浸透, 侵入す るケースもある。一方, 不定形耐火物は目地のない均質な炉 壁を建築することができる。

\section{2 化学組成による分類}

耐火物を化学組成によって, 塩基性, 中性, 酸性に分類す る方法は，かなり古くから用いられてきた。これは，塩基性 耐火物の熱膨張係数が大きいことや耐熱性が高いこと, 塩基 性スラグに対して侵食されにくいこと, 塩基性と酸性の耐火 物が隣接した場合に接触部分の溶損が進むなどという現象に 基づいている。これは耐火物自体が化学的にアルカリ性で あるという意味ではない。このように耐火物の化学組成に よって材料特性が異なるのは, 耐火物を構成する元素の並び 方 (結晶構造) が異なり, これが材料特性に強く関わってい るためである。化学組成による塩基性, 中性, 酸性の分類は 表 $2^{1 ）}$ に示すとおりであり，金属元素を Rとした場合に，塩 基性はRO成分を主体とした耐火物である。 $\mathrm{RO}$ は，金属（R） イオンと酸素（O）イオンが規則正しく緻密に充填した結晶 構造（図 $1^{2)}(\mathrm{a})$ ) をしている。一方, 酸性は $\mathrm{RO}_{2}$ 成分を主体 とした耐火物であり， $\mathrm{RO}_{2}$ は，中心に金属 $(\mathrm{R})$, 頂点に酸 素（O）が位置した四面体が，頂点で繋がった隙間の多い結

\footnotetext{
*AGCセラミックス株式会社＼cjkstart新規事業開発グループ（テ108-0014 東京都港区芝4-1-23 三田NNビル 6F） New Business Development Group, AGC Ceramics Co., Ltd. (4-1-23 Shiba, Minato-ku, Tokyo 108-0014) E-mail: kazuya-noda@agc.com 受付日：平成28年2月18日＼cjkstart受理日：平成28年3月 3 日
} 
晶構造（図 $1^{2)}(\mathrm{b})$ ) をしている。 $\mathrm{SiO}_{2}$ にいくつかの種類の結 晶構造が存在するのは，三次元的な四面体の並び方がいろい ろ可能なためである。これらの結晶構造と, 熱膨張特性や耐 熱性，耐食性などの材料特性が強く関わっている。

熱膨張特性は，熱を受けたときにイオンの熱振動によって 結晶が大きくなり，材料が膨張する現象である。 ROはイ才 ンが規則正しく緻密に充填した構造をしているため，イオン の熱振動が材料の膨張に及ぼす影響が大きく，熱膨張率も大 きい值を示す。一方， $\mathrm{RO}_{2}$ は隙間の多い構造をしており，原 子の熱振動の影響は結晶内で吸収されるため, 熱膨張率も小 さい值を示す。熱を受けたときに結晶構造が崩れる状態が溶 けるという現象である。規則正しい構造をしたROは，熱を 受けたときにも構造が崩れにくく耐熱性が高い性質を示す が，隙間の多い構造をした $\mathrm{RO}_{2}$ は構造が崩れやすく，耐熱性 が低い。中性耐火物は $\mathrm{R}_{2} \mathrm{O}_{3}$ 成分を主体とした耐火物であり, 酸性耐火物と塩基性耐火物の中間的な性質を示す。

最近の耐火物製品は複雑になってきており，化学組成によ る単純な分類が難しくなってきているが，上記は材料特性を 理解するうえで参考となる。

\section{3 状態図（相図）}

常温で固体（固相状態）である耐火物は，高温になると溶 融して液体（液相状態）となる。単一組成の物質が溶融する 温度（融点）はそれぞれ表3に示したとおりであるが，第2 成分や第 3 成分が加わると，その物質の融点は変化する。化 学成分ごとに平衡状態における固相と液相の状態を示したも のに平衡状態図というものがある。状態図と呼ばれることや 相図といわ机ることがある。図 $2^{3)}$ に $\mathrm{Al}_{2} \mathrm{O}_{3}-\mathrm{SiO}_{2}$ の 2 成分系 の状態図を示す。融点の低いアルミニウムの場合には，溶解 炬の温度も低いために，製鉄プロセスのように耐火物が溶損

表 2 耐火物の化学組成による分類 ${ }^{1)}$

\begin{tabular}{|c|c|c|c|}
\hline 分類 & 化学組成 & 熱膨張特性 & 耐熱性 \\
\hline $\begin{array}{l}\text { 酸性耐火物 } \\
\left(\mathrm{RO}_{2}\right)\end{array}$ & $\begin{array}{l}\mathrm{SiO}_{2} \text { 系 } \\
\mathrm{SiO}_{2}-\mathrm{Al}_{2} \mathrm{O}_{3} \text { 系 } \\
\mathrm{ZrO}_{2} \text { 系 }\end{array}$ & 小 & 低 \\
\hline $\begin{array}{l}\text { 中性耐火物 } \\
\left(\mathrm{R}_{2} \mathrm{O}_{3}\right)\end{array}$ & $\begin{array}{l}\mathrm{Al}_{2} \mathrm{O}_{3} \text { 系 } \\
\text { スピネル系 } \\
\mathrm{Cr}_{2} \mathrm{O}_{3} \text { 系 }\end{array}$ & 中 & 中 \\
\hline $\begin{array}{l}\text { 塩基性耐火物 } \\
\text { (RO) }\end{array}$ & $\begin{array}{l}\mathrm{MgO} \text { 系 } \\
\mathrm{MgO}-\mathrm{Cr}_{2} \mathrm{O}_{3} \text { 系 } \\
\mathrm{MgO}-\mathrm{CaO} \text { 系 }\end{array}$ & 大 & 高 \\
\hline
\end{tabular}

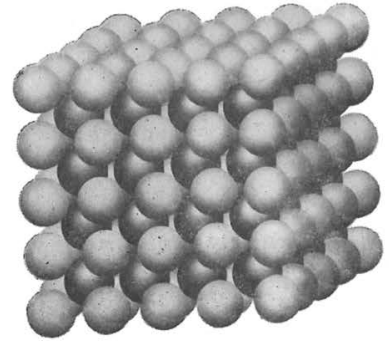

（a）塩基性耐火物（RO）
することはない。

\subsection{Ellingham (エリンガム) 図}

耐火物の多くは金属酸化物で構成され，高温かつ還元䨌囲 気 (酸素分圧が低い) で使用される。この金属酸化物が酸素 と解離して金属の状態が安定であるのか, 金属酸化物の状 態が安定であるのかを示したエリンガム図 (図 $3^{4)}$ ) という ものがある。この図を見れば, $\mathrm{SiO}_{2}$ と $\mathrm{Al}$ が共存する場合に， $\mathrm{SiO}_{2}$ が還元されて $\mathrm{Si}$ となり, $\mathrm{Al}$ が酸化して $\mathrm{Al}_{2} \mathrm{O}_{3}$ となる状態 が安定であることが，すぐに読み取ることができる。

エリンガム図が示しているように，アルミニウム溶解炬で 使用される耐火物に含まれる $\mathrm{SiO}_{2}$ は，アルミニウム溶湯と 反応して $\mathrm{Si}$ に還元し， $\mathrm{Al}$ は酸化して $\mathrm{Al}_{2} \mathrm{O}_{3}$ になる。これが後 述する耐火物の「黒色化」や「オバケ」に強く関連した化学 反応である。

表 3 単一組成物質の融点

\begin{tabular}{lc|c}
\hline \hline \multicolumn{2}{|c|}{ 化学組成 } & 融点 $\left({ }^{\circ} \mathrm{C}\right)$ \\
\hline $\mathrm{SiO}_{2}$ & シリカ & 1713 \\
$\mathrm{TiO}_{2}$ & チタニア & 1840 \\
$\mathrm{Al}_{2} \mathrm{O}_{3}$ & アルミナ & 2050 \\
$\mathrm{Cr}_{2} \mathrm{O}_{3}$ & クロミア & 2265 \\
$\mathrm{CaO}$ & カルシア & 2570 \\
$\mathrm{MgO}$ & マグネシア & 2800 \\
\hline
\end{tabular}

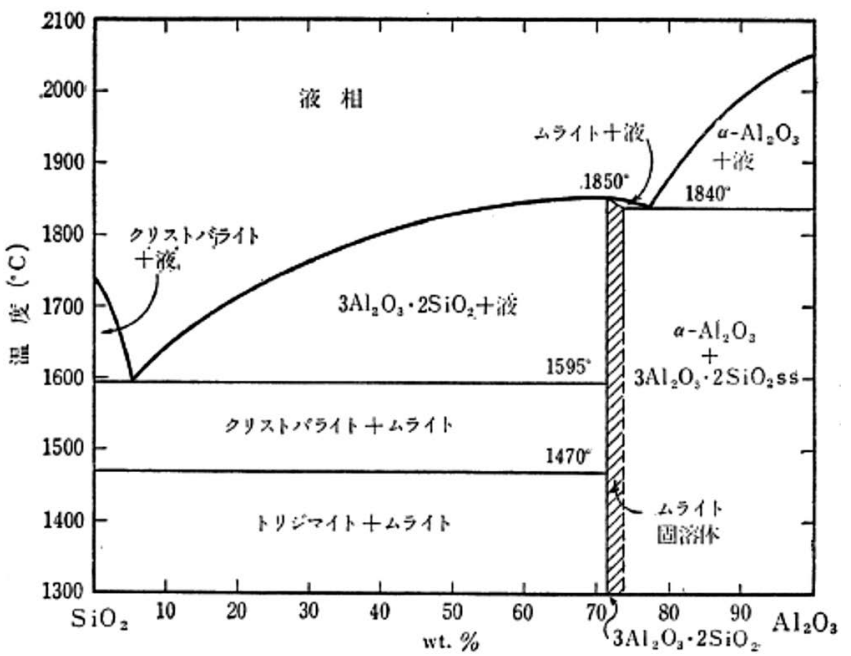

図2 $\mathrm{Al}_{2} \mathrm{O}_{3}-\mathrm{SiO}_{2}$ の2 成分系状態図 ${ }^{3)}$

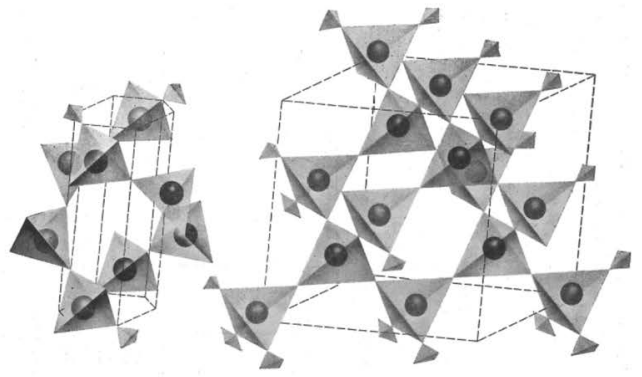

(b) 酸性而火物 $\left(\mathrm{RO}_{2}\right)$

図1 各種耐火物の結晶構造 ${ }^{2}$ 


\section{5 耐火物の微細組織}

耐火物製品の材料特性は, 材料を構成する化学組成や結晶 構造だけで説明することができない。耐火物はマクロ的にみ ても不均質な組織を有しており，この組織の状態が材料特性 に関係している。「結合耐火物」や「不定形耐火物」に見ら れる代表的な微細組織の概念図を図4に示す。これらは，大 きさが数 $\mathrm{mm}$ から数百 $\mu \mathrm{m}$ の耐火骨材からなる「骨材相」と, 不定形耐火物であれば，大きさが数百 $\mu \mathrm{m}$ 以下の耐火骨材や 超微粒子, アルミナセメント, 分散剤, そして微細な気孔 (ミ クロ気孔）からなる「マトリックス相」，そして「マクロ気孔」 で構成される。不定形耐火物炉壁の微細組織が, 施工条件に よって影響を受けるものに,「マクロ気孔」や「ミクロ気孔」 がある。現地施工作業が所定条件で実施されず，「マクロ気 孔」の多い炉壁になった場合に，設計どおりの性能が発揮さ

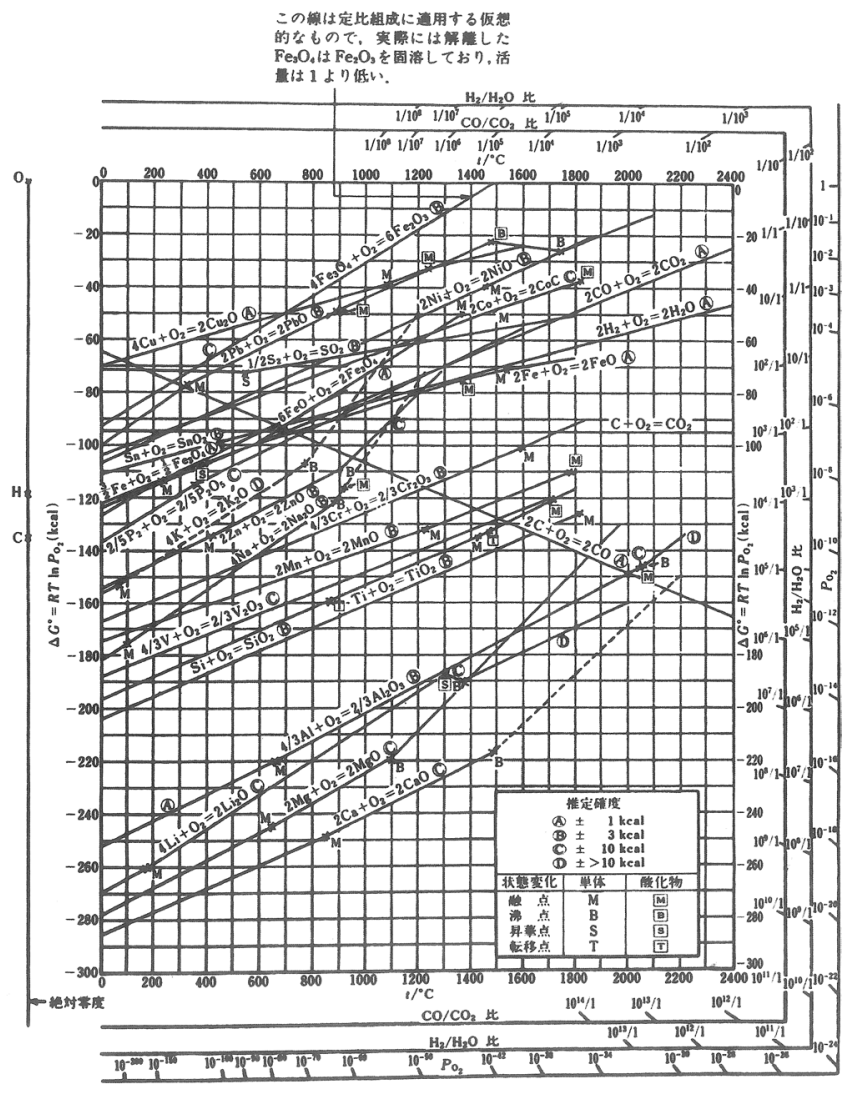

図3エリンガム図 ${ }^{4)}$
れないことがある。また施工時の混練水量が多くなった場合 に「ミクロ気孔」の多い炉壁となり，設計どおりの性能が発 揮されないことがある。

\section{3. アルミニウム産業で使用される主な耐火物の特徵}

\section{1 アルミニウム産業で使用される耐火物}

耐火物の製造方法や化学成分による分類からもわかるとお り，耐火物の製品には非常に多くの種類があり，その性能に は一長一短がある。各耐火物製品の特性や高温設備の炬内条 件，使用された耐火物の損耗形態などをよく理解したうえ で，耐火物製品の選定を行う必要がある。

アルミニウム産業における高温設備は，アルミニウム製品 の製造プロセスによって，その種類や大きさなどはさまざま である。また各設備で使用される耐火物も，炉内条件や使用 された耐火物の損耗形態などから適正材質の選定がなされ る。一般的なアルミニウム溶解・保持炉の耐火物ライニング 構成を図 $5^{5)}$ に, 適用されるキャスタブル耐火物の品質例を 表4に示す。これらの設備では, 以前には「結合耐火物」が 使用されることが多かったが，最近では不定形耐火物の一種 である「キャスタブル耐火物」が採用されているようである。 「キャスタブル耐火物」を使用するメリットとしては，目地 のない均質な炉壁が建築できるため，アルミニウム溶湯の浸 透を軽減できることが挙げられる。また「キャスタブル耐火 物」の一種である「低セメント系キャスタブル」は非常に緻 密な微細組織を有しているため, アルミニウム溶湯の浸透に 対する抵抗性にも優れている。こういった特長を示す一方 で，使用上の留意点がいくつかあるため後述する。

\section{2 アルミニウム産業で使用される耐火物の損傷}

融点の高い金属の溶解炉では, 高温下で溶けた金属やス ラグが耐火物と反応して，生成した低融点物質が溶出した り，耐火物が変質することにより，耐火物の損傷が進む。低 融点物の生成や耐火物の変質については，前述の状態図から 推定することができる。一方, 融点の低いアルミニウムの場 合には，溶解炉の温度も $700 \sim 850^{\circ} \mathrm{C}$ と低いために，低融点 物質の生成による耐火物の損傷は起こらない。しかしアルミ ニウムの溶湯は, 表面張力が約 $0.6 \mathrm{~N} / \mathrm{m}$ と低く, 耐火物に浸 透しやすい。また還元力が強いために, 耐火物中の酸化物 を還元して，自らは酸化してアルミナ $\left(\mathrm{Al}_{2} \mathrm{O}_{3}\right)$ になる。ア ルミニウム溶湯の浸透と還元反応による変質層の生成, そし て操業中の温度変化やアルミニウム溶湯の湯面上下などに
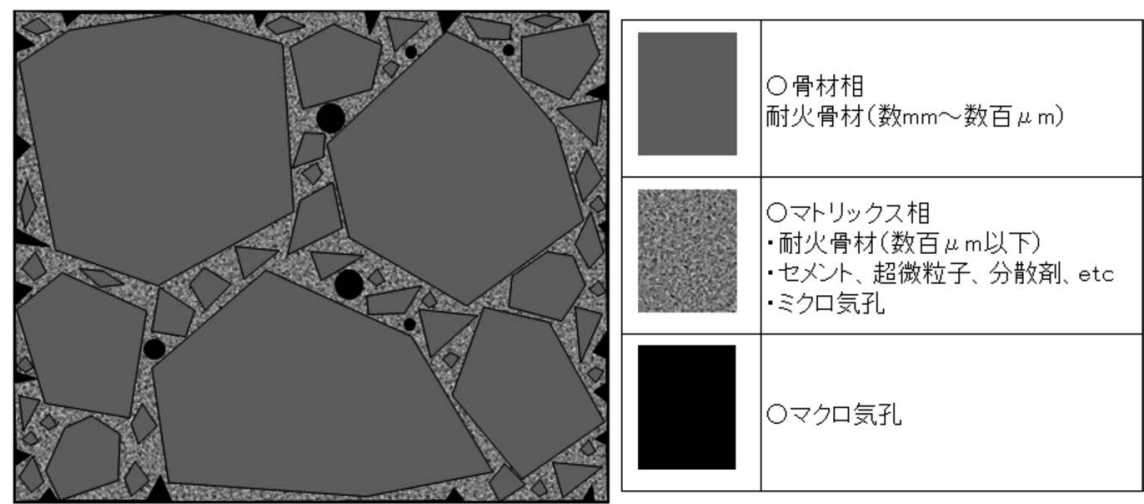

図4 結合耐火物や不定形耐火物に見られる代表的な微細組織（概念図） 


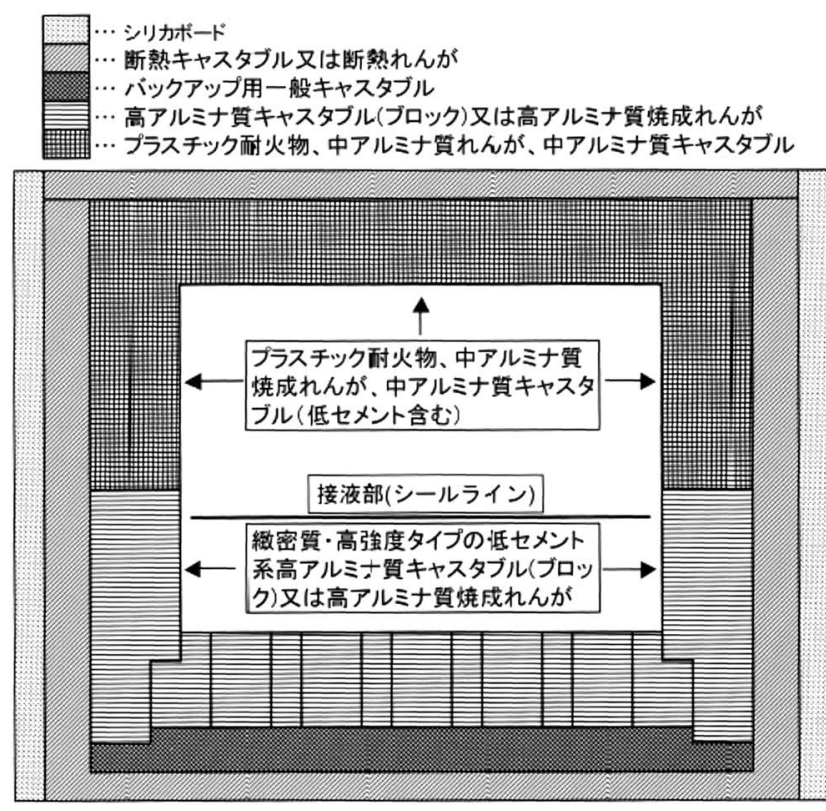

図 5 一般的なアルミニウム溶解・保持炉の耐火物ライ ニング構成 ${ }^{5)}$

よって, 耐火物の変質・損傷が進む。変質層の色調が黒色で あることから，変質層の生成を「黒色化」と表現することが ある。酸化・還元反応の起こりやすさについては，前述の Ellingham（エリンガム）図から推定することができる。ア ルミニウム溶湯中にマグネシウムなどの蒸気圧の高い金属を 含む場合には，耐火物の損傷はより進みやすくなる。炉内温 度が高い場合などには，湯面から上部の耐火物壁面に，黒色 の強固で緻密な酸化物が生成することがある。これが大きく 成長した場合には操業を阻害することがあり，「オバケ」と も呼ばれている。

以上のとおり，浸透したアルミニウム溶湯による還元反応 が，耐火物損傷の主な要因となっており，アルミニウム溶湯 に接触する部位に使用される耐火物製品は，(1)組織を緻密に してアルミニウム溶湯の浸透抵抗性を高める, (2)アルミニウ ム溶湯の浸透防止剂を使用する, (3)アルミニウム溶湯に還元 されにくい組成にする，などの工夫がなされている。

\section{3 低セメント系キャスタブル}

製造方法により分類された「不定形耐火物」であるが，耐 火物原料を混合しただけの形状をもたない耐火物製品であ り，プラントに合わせて現地で形つくられて炉壁となる。こ のため現地施工に便利なように，不定形耐火物にはさまざま な種類がある。その主な種類と施工方法を表 5 に示す。

「キャスタブル耐火物」の一種である「低セメント系キャ スタブル」は，非常に緻密な微細組織を有しており，材料強 度が高く，耐食性にも優れており，さまざまな高温設備にお いて広く使われている。その緻密な微細組織からアルミニウ 厶溶湯の浸透に対する抵抗性にもたいへん優れており，アル ミニウム産業においても広く使用されている。

施工硬化後の「キャスタブル耐火物」炉壁には，混練水が 自由水や結晶水（セメント水和物）という形態で残ってい る。これらの炉壁中の水分は，アルミニウム溶解処理前の乾 燥・熱上げの過程で消失し，その消失跡は耐火物中では「ミ クロ気孔」として残る。このため混練水を施工可能な範囲で
表4 アルミニウム溶解・保持炉に使用されるキャス夕 ブル耐火物の品質例

\begin{tabular}{|c|c|c|c|c|}
\hline & \multicolumn{2}{|c|}{$\begin{array}{c}\text { 化学成分 } \\
(\%)\end{array}$} & かさ比重 & $\begin{array}{c}\text { 圧縮強さ } \\
(\mathrm{MPa})\end{array}$ \\
\hline & $\mathrm{Al}_{2} \mathrm{O}_{3}$ & $\mathrm{SiO}_{2}$ & \multicolumn{2}{|c|}{$110^{\circ} \mathrm{C}-24 \mathrm{~h}$} \\
\hline $\begin{array}{l}\text { 高アルミナ質 } \\
\text { キャスタブル }\end{array}$ & 84 & 10 & 2.95 & 80 \\
\hline $\begin{array}{l}\text { 中アルミナ質 } \\
\text { キャスタブル }\end{array}$ & 63 & 31 & 2.45 & 45 \\
\hline 一般キャスタブル & 85 & 5 & 2.6 & 45 \\
\hline 断熱キャスタブル & 33 & 39 & 0.85 & 2.5 \\
\hline
\end{tabular}

表 5 不定形耐火物の主な種類と施工方法

\begin{tabular}{l|l}
\hline \hline & \multicolumn{1}{|c}{ 施工方法 } \\
\hline $\begin{array}{l}\text { キャスタブル耐火物 } \\
\text { 流し込み施工耐火物 } \\
\text { 振動施工キャスタブル } \\
\text { セルフフローキャスタブル }\end{array}$ & $\begin{array}{l}\text { 粉末状製品で, 水などで混 } \\
\text { 練し, 流し込む }\end{array}$ \\
\hline コテ塗り施工耐火物 & 粉末状製品で, 水などで混練 \\
& し, コテを使って塗り込む \\
\hline 吹付施工耐火物 & 粉末状製品で, 専用機械を \\
& 使って, 吹き付ける \\
\hline 打ち込み施工耐火物 & 練り土状製品で, エアラン \\
& マーなどで打ち込む \\
\hline
\end{tabular}

極力減らすことが，健全な耐火炉壁を建築するうえでたいへ ん重要となる。「低セメント系キャスタブル」は, 混練水量 を大幅に低減した「キャスタブル耐火物」であり，炉壁は緻 密な微細組織を有する。「低セメント系キャスタブル」には, 原料として平均粒子径 $1 \mu \mathrm{m}$ 以下の超微粒子が配合されてい る。この超微粒子を特殊な分散剤などで均一に分散させるこ とによって, 混練水量を極限まで減じることを可能としてい る。「キャスタブル耐火物」の適正な混練水量は, 製品LOT によって多少変わるため, その都度施工現場で調整する必要 がある。この適正水量が変動する要因はさまざまであるが, 主なものとして使用される原料の化学成分や嵩比重などの品 質変動が挙げられる。

\section{4. 低セメント系キャスタブルを使用するうえでの 留意点}

アルミニウム溶湯の浸透抵抗性に優れた炉壁を実現した 「低セメント系キャスタブル」であるが，以下の点に気をつ けて炉壁を建築することによって, その性能を最大限に発揮 させることができる。

\section{1 混練水量}

「キャスタブル耐火物」の物性は，混練水量の影響を大き く受ける。これは「低セメント系キャスタブル」の場合にそ の傾向が大きい。このため混練水を施工可能な範囲で極力減 らすことが，健全な耐火炉壁を建築するうえで重要となる。 「低セメント系キャスタブル」の物性に及ぼす混練水量の影 響の測定例を図 $6^{6)}$ に示す。 


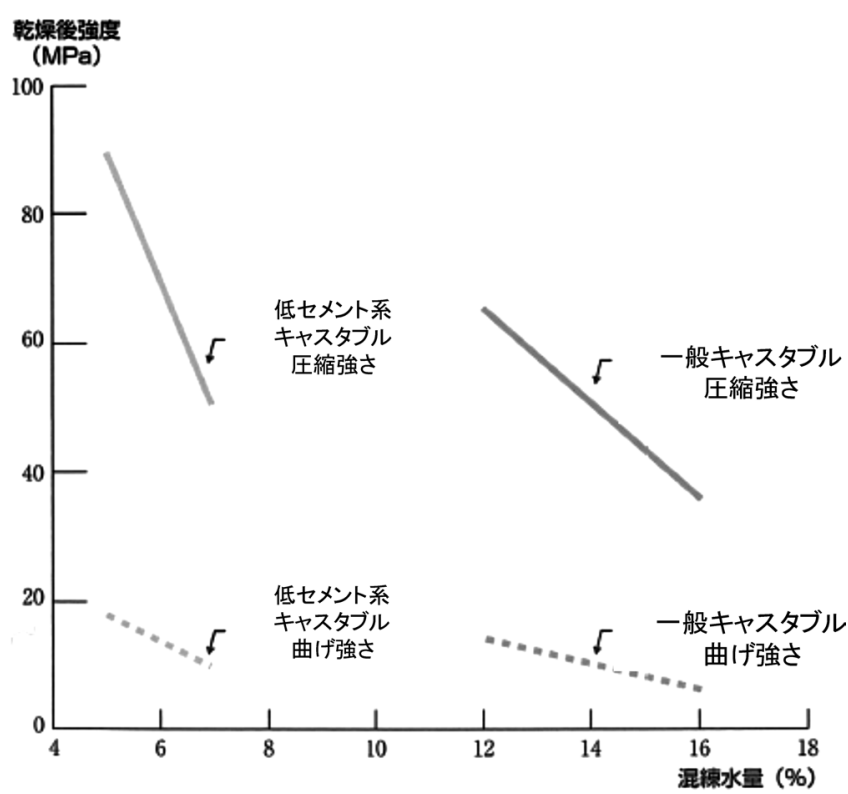

図6キャスタブル耐火物の乾燥後強度に及ぼす混練水 量の影響6)

\section{2 混練時間}

混練時間をしっかりと確保することが，混練水量を減らす うえで有効となる。「低セメント系キャスタブル」の場合に は，その傾向が特に顕著であり，3分間以上の混練時間を確 保することが望ましい。混練水量を増やすことで混練時間を 短縮することが可能となるが，混練時間をしっかりと確保す ることが，混練水量の低減，そして健全な炉壁の建築につな がる。

\section{3 硬化調整}

混練開始後の「キャスタブル耐火物」は, 時間の経過とと もに流動性が低下し, 固まる（硬化する）。混練開始後, 施 工可能な流動性が維持されている時間を『可使時間』とい い, 流動性がなくなってから時間の経過とともに硬化体の強 度が発現し，強度が飽和するまでの時間を『硬化時間』とい う。施工時に分散していた超微粒子は，時間の経過とともに 凝集しはじめ, 流動性が低下し, やがて『可使時間』が訪れ る。この超微粒子の凝集という現象が気温の影響を大きく受 ける。夏期には凝集が早くなり『可使時間』が短くなる傾向 にあるが，「硬化遅延剂」を用いることによって施工時間を 確保することができる。冬期には『硬化時間』が長くなる傾 向にあるが，「硬化促進剤」を用いることによって，効率的 な炉壁建築を行うことができる。「硬化遅延剤」や「硬化促 進剂」を使用しなかった場合の，一般的な「低セメント系キャ スタブル」の『可使時間』『硬化時間』の測定例を図 $7^{6)}$ に示す。

\section{4 施工体の乾燥}

施工硬化後の「キャスタブル耐火物」炉壁には，混練水が 自由水や結晶水 (セメント水和物) という形態で残っている。 この炉壁の使用前には，水分を除去するために炉壁を加熱乾 燥する。この乾燥時のトラブルとして，炉壁内部で発生する

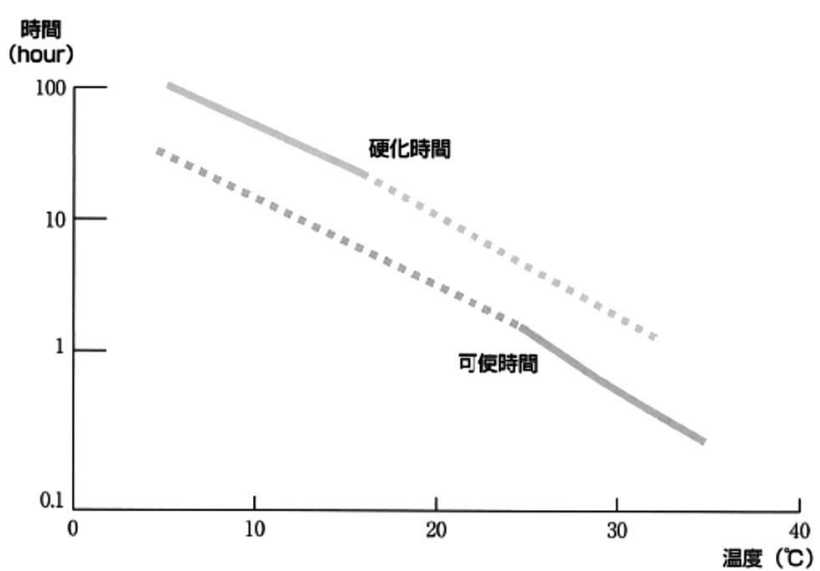

図7 一般的な「低セメント系キャスタブル」の『可使 時間』『硬化時間』の測定例 ${ }^{6}$ (「硬化遅延剂」や「硬 化促進剂」を使用しなかった場合）

水蒸気の圧力で炉壁が壊れる『爆裂』という現象がある。非 常に緻密な微細組織を有する「低セメント系キャスタブル」 は炉壁から水分が抜けにくいために, 水蒸気の圧力が高くな る傾向にある。この爆裂に対する抵抗性を評価する方法とし て, 材料サンプルの片面加熱乾燥や, 高温の宰へ材料サンプ ルを投げ込む試験がある。これらの実験結果と実炉での経験 から, 耐火物メーカー各社が, 炉壁乾燥時の加熱プログラム を設定している。近年, 耐爆裂性の評価のために, 乾燥中の 炉壁内部蒸気圧の測定が試みられており ${ }^{7)}$, 急速乾燥可能な キャスタブル製品の開発に活用されている。

\section{5. 最近の取り組み}

高温プラントを有する鉄鋼，非鉄金属，ガラス，セメント 製造などのエネルギー大量消費型産業では，企業の環境意識 の高まりから, 製造工程の省工ネ化が進められている。工業 炉からの熱漏れを防ぐことによって, エネルギー効率を高め ることは, 省エネに有効な手段であることから, より高い断 熱性をもつ炬材が求められている。最近では従来の断熱層用 キャスタブル耐火物に比べて，より低熱伝導化された製品の 開発や, 炉内層用キャスタブル耐火物の低熱伝導化が試みら れており，アルミニウム製造プラントでもその省エネルギー 効果だけでなく，耐用の実績も確認されている ${ }^{8), 9)}$

\section{参 考 文 献}

1）耐火物とその応用，耐火物技術協会，(1979），12.

2) ジョン・ウルフ編: 物質の構造 (材料科学入門 I), 岩波書 店, (1967)，50

3）吉木文平：耐火物工学，技報堂，（1962），289.

4) 丸山俊夫, 上田光敏：耐火物, 58 (2006), 218-222.

5）軽金属学会：研究部会報告書No. 48, (2006), 4.

6) AGCセラミックス(株)タタグ，不定形耐火物。

7) 小田健嗣, 伊藤 肇, 大橋浩二, 㫟本隆成, 小野泰史：耐火物, 42 (1990), 389-397.

8) 小野泰史, 野田和也, 加藤田一平, 阿部良司, 津田浩人, 佐藤 芳則：工業加熱，53 (2016)，11-16.

9）省エネルギー， 68-2（2016）, 74-75. 